\title{
REDUCING SOPHOMORE STUDENTS' DILEMA IN CREATING AN APPEALING TEACHING MEDIUM THROUGH SLIDESGO USAGE
}

\author{
Lulud Oktaviani ${ }^{1}$, Fatimah Mulya Sari ${ }^{2}$ \\ ${ }^{1,2}$ Universitas Teknokrat Indonesia \\ email: ${ }^{1} 1$ ulud_oktaviani@ teknokrat.ac.id
}

\begin{abstract}
Teachers is not only teaching or delivering materials in a class but also being a professional in all aspects of teaching. Teachers cannot ignore their students' understanding or characteristics in every teaching and learning activity. Moreover, a teacher is considered as a professional job in Indonesia. Thus, they also get additional payment for being a professional as long as they have got a certificate of professionalism. As sophomore students of English Literature in Universitas Teknokrat Indonesia are having some pedagogical subjects which give them a choice to be an English teacher in the future, they take Teaching Material Design (TMD) in their fourth semester. The subject covers how to design a teaching set, prepare a material and media, and learning evaluation. Unfortunately, $86 \%$ students thought in preparing teaching media needed more time to prepare and a specific knowledge, especially which is interesting and takes less time in making. So, the researchers give an alternatives medium that has a template theme and interesting, slidesgo. It has many advantages, so they can use it in teaching and suit the theme with the material they are going to teach. In the end, most of the students were glad and thought that it made them easy to prepare teaching media and took less time.
\end{abstract}

Key words: teaching media, English teachers, teaching and learning

\section{INTRODUCTION}

Being a teacher is not only delivering materials to the students but also being a professional educator which also guiding and improving their students' competence and value. As Law of the Republic of Indonesia Number 14 of 2005 concerning teachers and lecturers stated that: "Guru adalah pendidik profesional dengan tugas utama mendidik, mengajar, membimbing, mengarahkan, melatih, menilai dan mengevaluasi peserta didik pada pendidikan anak usia dini jalur pendidikan formal, pendidikan dasar, dan pendidikan menengah." Nowadays, teachers are considered as a professional job in Indonesia. It is in line with Minister of Education and Culture Regulation (Permendikbud) Number 37 of 2017 Article 1 Paragraph 2 that "Sertifikat pendidik adalah bukti formal sebagai pengakuan yang diberikan kepada guru sebagai tenaga professional." Thus, there is a certain standard and proof for those who so-called as a 
professional teacher. Demirkasımoğlu (2010) said that a teacher professionalism is meeting certain standard of teacher' work proficiency and improving their public image. Thus, if ones want to be considered as a professional teacher, they need to achieve and fulfill its requirements and characteristics. Moreover, Berliner (2004) said that expert teachers' characteristics are mastering the material they are going to teach and plan one or more activities to teach the material by considering students' cognitive level, personality, and history background. So, based on the previous theories, a professional teacher has to master the contents that they are going to teach and suit it with students' characteristics in order to improve their self-image, and get a notice from the government as a formal proof with a professionalism certificate.

As a professional teacher needs to plan and suit the content with their students' characteristics, he/she can also use many ways to achieve that aims, one of them is utilizing a technology or internet in teaching and learning activities. Oktaviani and Desiarti (2017) said that technology usage in teaching and learning process can maximize students' potential who are as digital native. Nawaila et. al. also (2020) said that the use of technology in teaching and learning process has been increased in the past three years and made it more productive and interesting because technology can be suited with any level of teacher and students. Moreover, Ahmadi (2018) stated that the use of technology can facilitate and improve the quality of language learning. In line with the previous theories, Aminatun and Oktaviani (2019) said that using technology in teaching and learning process can stimulate students' autonomous learning since they can open it everywhere and anytime with or without teachers' guidance. By seeing to those technology usage, teachers are encouraged to apply it in a teaching plan to support their professionalism.

There are many kind of technology that can be applied in teaching and learning activities especially digital technology. According to Erdin (2020), digital technology is electronic tools, devices, or sources which create, process, or store data, such as social media, multimedia, online games, or mobile phones. has been some example of technology usage in teaching and learning process. For example, Sari and Putri (2019) implemented Whatsapp group in Writing Class. Besides, Oktaviani et. al. (2020) applied Powtoon as multimedia to teach in Reading Class. Despite many digital technologies usage which have been used to teach, it comes with some shortage such as take high cost, longer time, and more energy to learn and prepare. Thus, the researchers wanted to reduce at least this three burdens related to technology by proposing a free and open access application which has a template to be used in preparing a teaching material.

\section{METHOD}

A qualitative is used in this research because it discussed a phenomenology about individual's and group's experiences (Hameed, 2020). The aim of this research is to solve students' dilemma about technology usage in teaching and describe how to implement Slidesgo in teaching material. The subjects were 42 students of fourth semester in English Literature Study Program at Universitas Teknokrat Indonesia (UTI) who took English Teaching Media (ETM) subject.

\section{FINDINGS AND DISCUSSION}

The researchers gave a questionnaire to sophomore students of Universitas Teknokrat Indonesia (UTI) who took Teaching Material Design (TMD) subject, the result is shown below: 
Table 1. Preliminary Data

\begin{tabular}{|l|c|c|c|c|c|c|}
\hline \multicolumn{1}{|c|}{ Statements } & Always & \% & Sometimes & \% & Never & $\%$ \\
\hline $\begin{array}{l}\text { Digital technology helps me help me in } \\
\text { delivering material in interesting and attractive } \\
\text { ways. }\end{array}$ & 35 & 83 & 7 & 17 & 0 & 0 \\
\hline $\begin{array}{l}\text { Digital technology helps me in delivering the } \\
\text { material in order. }\end{array}$ & 37 & 88 & 5 & 12 & 0 & 0 \\
\hline $\begin{array}{l}\text { Digital technology helps me in remembering } \\
\text { the content of the material. }\end{array}$ & 33 & 79 & 9 & & 0 & 0 \\
\hline $\begin{array}{l}\text { Digital Technology helps me in interacting } \\
\text { with the students during teaching and learning } \\
\text { process. }\end{array}$ & 32 & 76 & 10 & 24 & 0 & 0 \\
\hline $\begin{array}{l}\text { Digital Technology can be used many times. } \\
\text { Digital Technology can stay and stand longer. }\end{array}$ & 42 & 100 & 0 & 0 & 0 & 0 \\
\hline $\begin{array}{l}\text { Digital Technology is difficult to adjust in } \\
\text { English material. }\end{array}$ & 0 & 0 & 7 & 17 & 32 & 76 \\
\hline $\begin{array}{l}\text { Digital Technology needs more time to } \\
\text { prepare. }\end{array}$ & 36 & 86 & 4 & 10 & 2 & 5 \\
\hline $\begin{array}{l}\text { Digital Technology needs a specific knowledge } \\
\text { to master. }\end{array}$ & 36 & 86 & 3 & 7 & 3 & 7 \\
\hline Digital Technology costs more. & 40 & 95 & 2 & 5 & 0 & 0 \\
\hline
\end{tabular}

From Table 1 above, the data showed that technology mostly gives many advantages in teaching and learning process. However, it gives burdensome and caused dilemma to sophomore students who took TMD subject because $86 \%$ students thought that it needs more time to prepare and specific knowledge to master. Sabzian et. al. (2013) said that teacher training students usually do not get enough exposure to technology. Moreover, 95\% students thought that it costs more.

There are some types of teaching media that can be used in delivering material from teachers to students, such as visual, audio, audio-visual, or even multimedia. According to Sukmahidayanti (2015), there are seven types of teaching media and one of them is computerbased technology that can be in a form of software or hardware. Computer-based technology also can be called as multimedia because it is a combination of text, audio or interactivity content (Ritakumari, 2019).

Slidesgo is a free Google Slides and Powerpoint Template. It is in a form of software and can be used as a teaching media. Moreover, it can be classified into computer-based technology in teaching because the teacher can combine text, picture, audio in this google slides. Slidesgo has a template that consists of many themes, such as business, education, economic, medical, and many more. For education itself, there are some themes for example thesis defense, workshop, school, and lesson. The following steps are how to use slidesgo for designing teaching material: 
a. Visit www.slidesgo.com
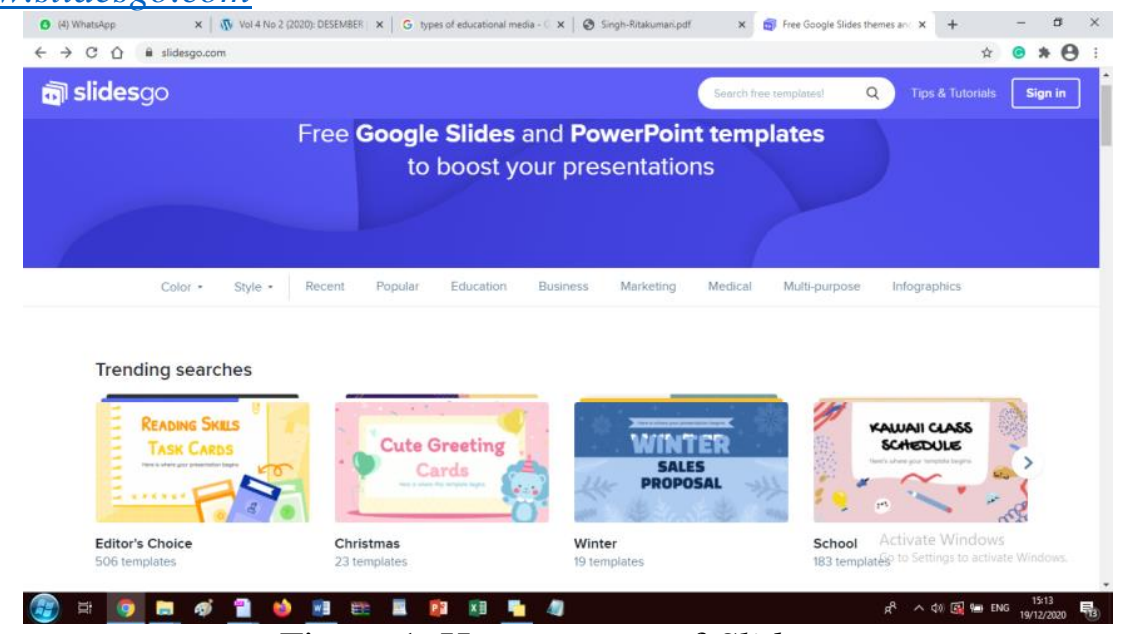

Figure 1. Home screen of Slidesgo

b. Search the theme or template that you want to find in top right corner.
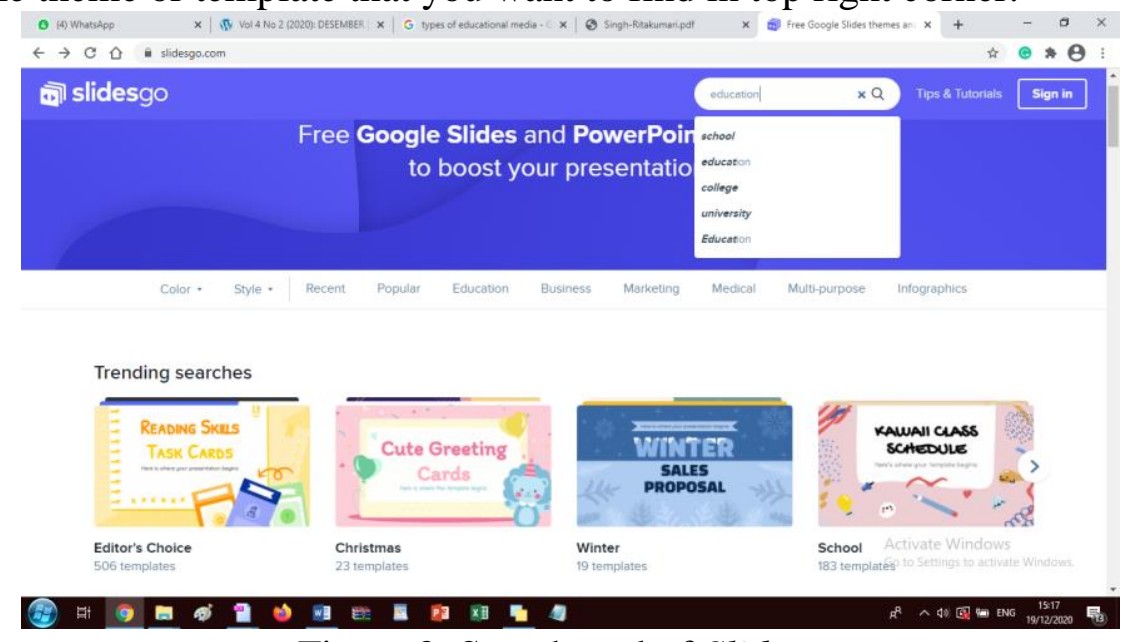

Figure 2. Search tool of Slidesgo

c. Choose the theme directly that suits teaching material without even do a registration because it is free.




Figure 3. Some examples of themes in slidesgo

d. Download the theme by clicking the button either google slides or power point.

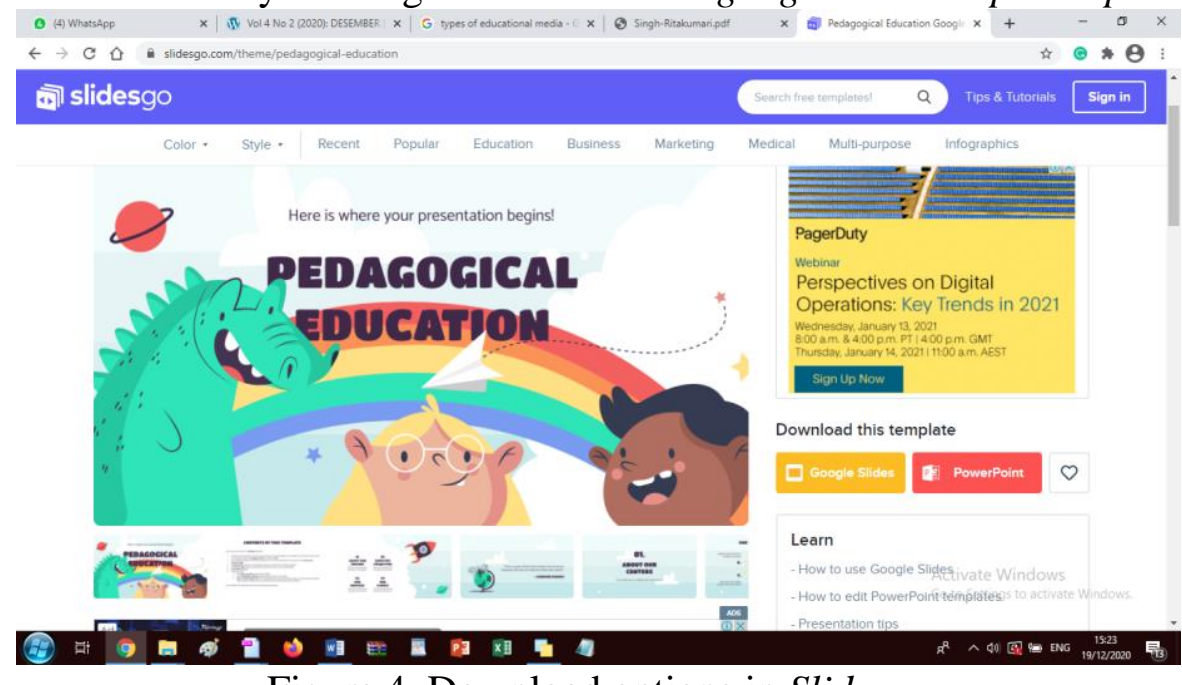

Figure 4. Download options in Slidesgo

e. Open the file in your computer and edit the template. The file has been consisted of picture, graphic, table, symbol, etc. that can be used.

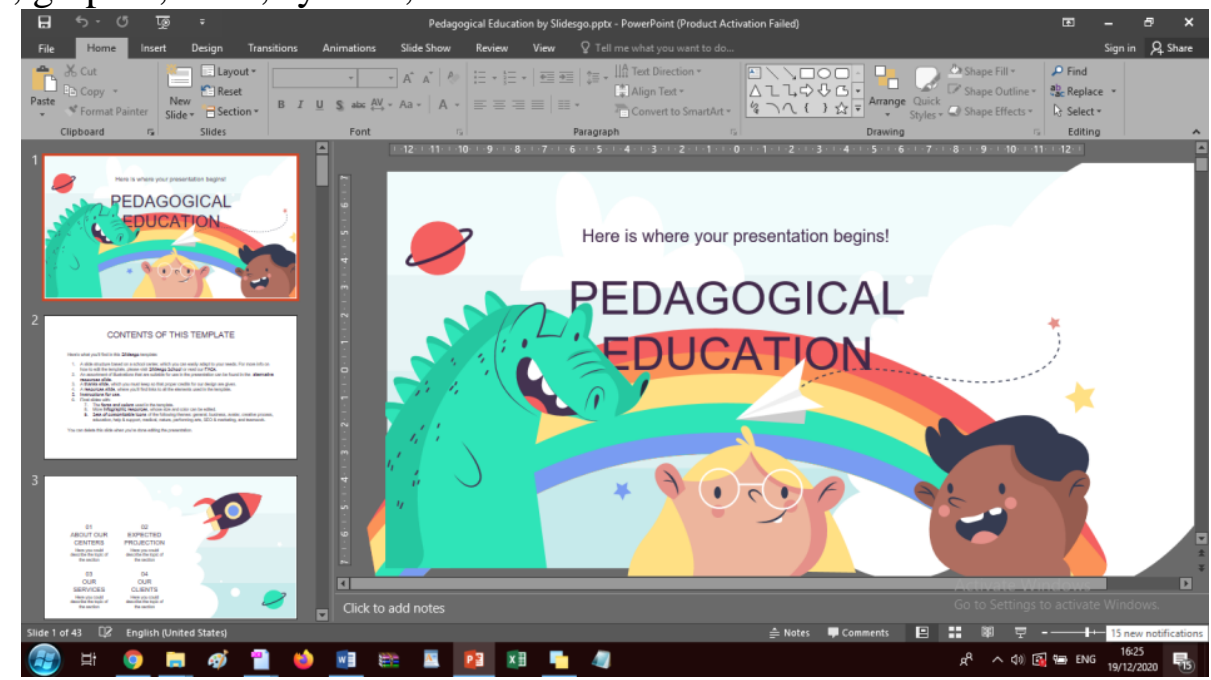

Figure 5. Inside Slidesgo Template (1) 


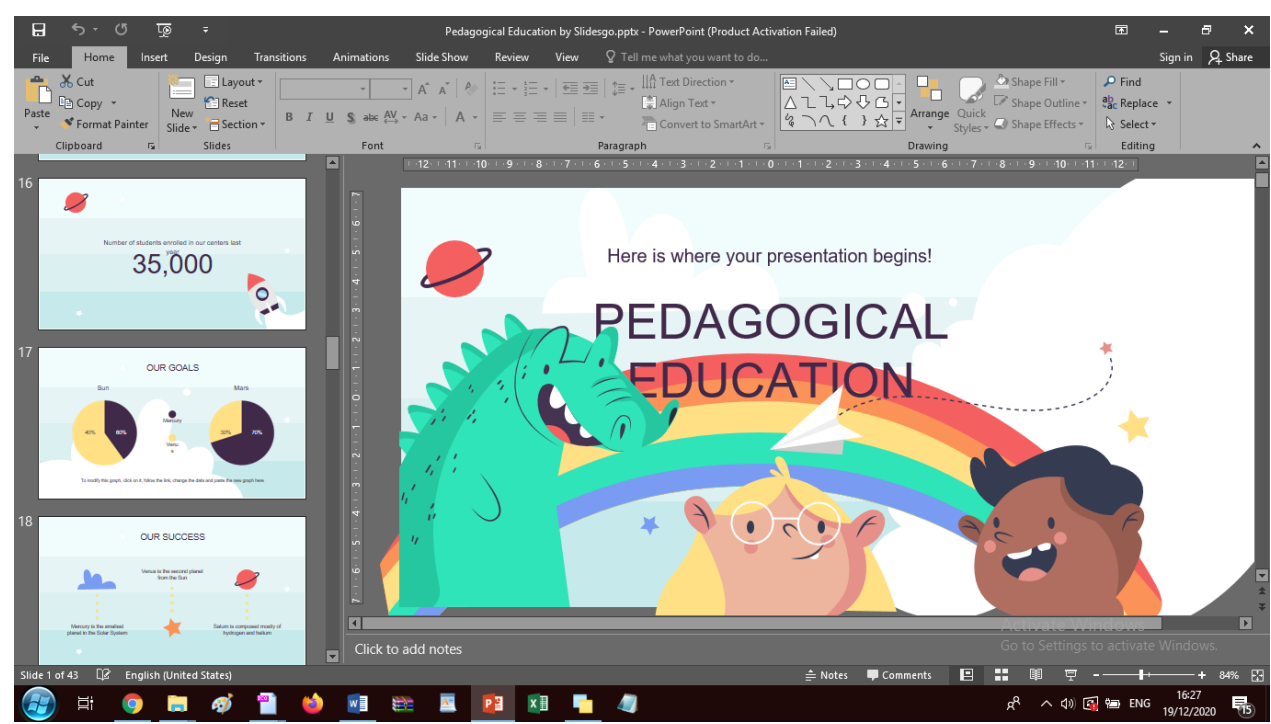

Figure 6. Inside Slidesgo Template (2)

f. Choose slide that suits your teaching material and delete the slides that you do not use. There is also alternatives resources in form of pictures, graphics, tables, icons, and symbols etc.

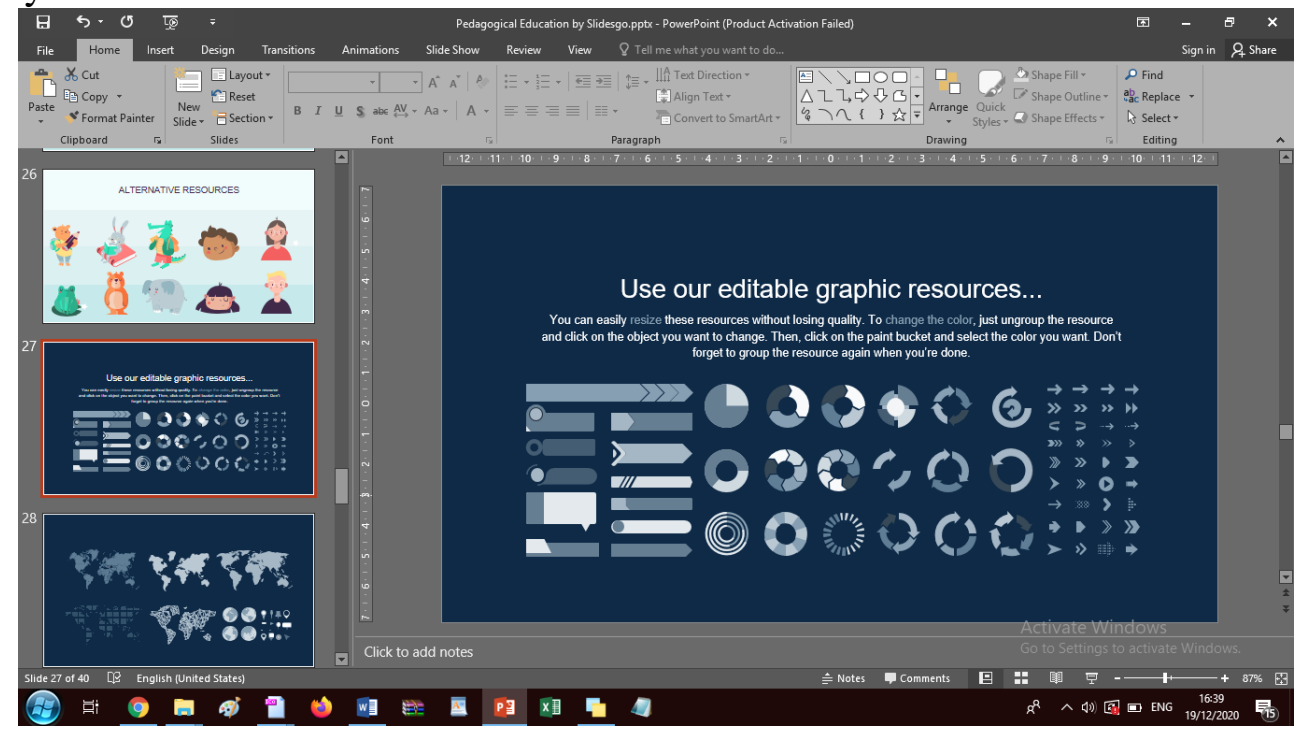

Figure 7. Alternatives resources in Slidesgo Template

g. After finishing your teaching material, save it.

h. Finally, use the PowerPoint to teach in a class.

Besides free, slidesgo also has a complete feature inside each template. So, the teacher or in this context students who took English Teaching Media (ETM) subject can save their time not to download pictures or icons that suit their teaching material and directly create teaching material. Moreover, how to use slidesgo is easy because the template can be downloaded directly without register or create an account. The theme of template itself is always upgraded by the company, so the teacher does not need to worry about the current theme. For example, corona 
virus has spread nowadays and the company has provided a corona virus template as shown in the figure 8 below.

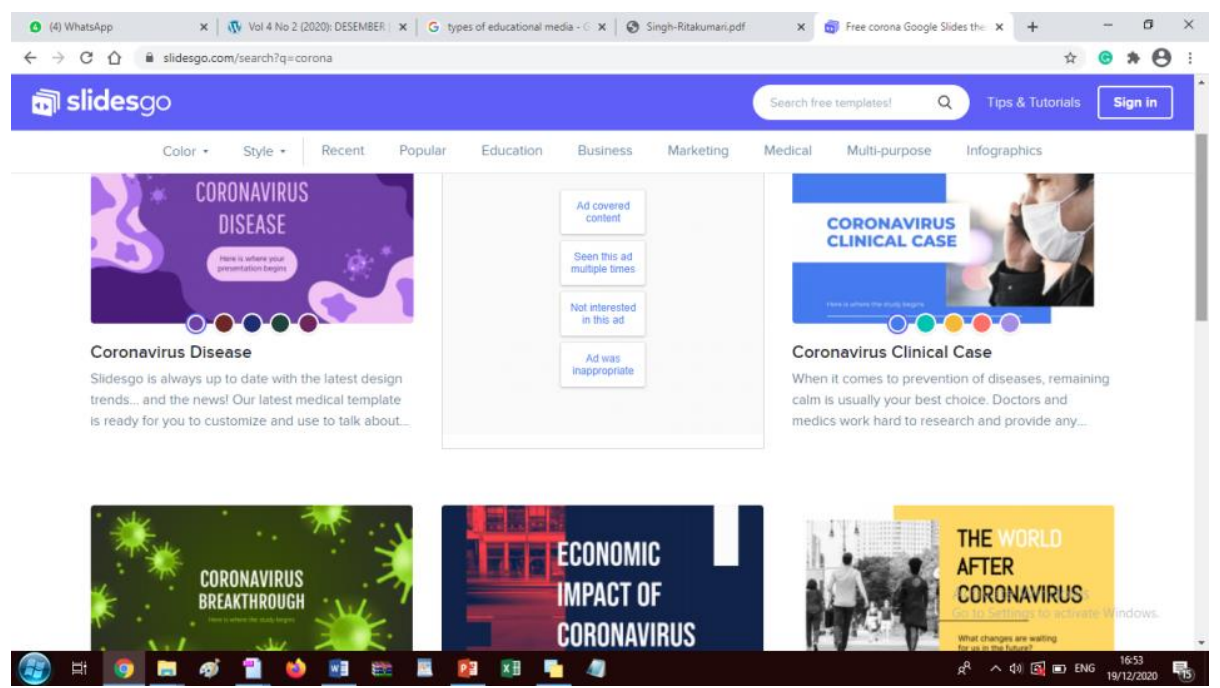

Figure 8. Corona Virus Template in Slidesgo

\section{CONCLUSION}

In conclusion, using digital technology in teaching and learning may give some advantages for both teacher and students. However, the use of it may also cause some weaknesses, such as it costs more, take more time to prepare, and need specific knowledge to create the teaching material. These weaknesses become burdensome to the students who took English Teaching Media (ETM) subject. After all, slidesgo can be used as a computer-based technology which cope those problems because it is free, easy to use, has a template and alternatives resources.

\section{REFERENCES}

Ahmadi, M. R. (2018). The Use of Technology in English Language Learning: A Literature Review. Iniernational Journal of Research in English Education (IJREE), 3(2): 115-125.

Aminatun, D. \& Oktaviani, L. (2019). Memrise: Promoting Students' Autonomous Learning Skills through Language Learning Application. Metathesis: Journal of English Language, Literature, and Teaching. 3(2), 214-224. DOI: 10.31002/metathesis.v3i2.1982

Berliner, J. (2004). Expert teachers: their characteristics, development and accomplishments. Retrievedfrom https://pdfs.semanticscholar.org/0b95/2838f63fca8f43661a1fc8bdea1238ec67d4.pdf. [accessed Nov 23 2020].

Demirkasımoğlu, N. (2010). Defining “Teacher Professionalism” from different perspectives. Procedia Social and Behavioral Sciences, 9: 2047-2051.

Erdin, Y. (2020). New Digital Technology in Education Conceptualizing Professional Learning for Educators (Book Review). Journal of Foreign Language Education and Technology, 5(1): 186-194. 
Hameed, H. (2020). Quantitative and Qualitative Research Methods: Considerations and Issues in Qualitative Research. The Maldives National Journal of Research, 8(1): 8-17.

Nawaila, M. B., Kanbul, S., \& Alhamroni, R. (2020). Technology and English Language Teaching and Learning: A Content Analysis. Journal of Learning and Teaching in Digital Age, 5(1): 16-23.

Oktaviani, L. \& Desiarti, E. (2017). A Lecturer's and Students' Perspective toward Ethnic Snake Game in Speaking Class at Universitas Muhammadiyah Malang. TEKNOSASTIK: Journal Bahasa dan Sastra. 15(2), 53-59. DOI: https://doi.org/10.33365/ts.v15i2.98

Oktaviani, L., Mandasari, B., \& Maharani, R. A. (2020). Implementing Powtoon To Improve Students'international Culture Understanding In English Class. Journal of Research on Language Education, 1 (1): 19-25.

Ritakumari, S. (2019). Educational Media in Teaching Learning Process. Bhartiyam International Journal of Education \& Research, 8(3): 7-14.

Republik Indonesia. (2005). Undang-undang No. 14 Tahun 2005 Tentang Guru dan Dosen. Lembaran Negara RI Tahun 2005, No. 1. Jakarta: Sekertariat Negara.

Sabzian, F., Gilakjani, A. P., \& Sodouri, S. (2013). Use of Technology in Classroom for Professional Development. Journal of Language Teaching and Research, 4(4): 684-692. Doi:10.4304/jltr.4.4.684-692.

Sari, F. M. \& Putri, S. N. (2019). Academic Whatsapp Group: Exploring Students' Experiences in Writing Class. TEKNOSASTIK: Journal Bahasa dan Sastra. 17(2), 56-65. DOI: https://doi.org/10.33365/ts.v17i2.324

Sukmahidayanti, T. (2019). The Utilization of Instructional Media in Teaching English to Young Learners (a Case Study of an Elementary School Teacher in Bandung). Journal of English and Education, 3(2): 90-100.

---------. (2017). Permendikbud Nomor 37 Tahun 2017 Pasal 1 Ayat 2 Tentang Sertifikasi Bagi Guru dalam Jabatan yang diangkat sampai dengan Tahun 2005. Jakarta: Kemendikbud. 